\begin{tabular}{|c|c|c|c|}
\hline & \multicolumn{2}{|c|}{ RESEARCH ARTICLE $\quad$ ARAŞTIRMA MAKALESİ } & \\
\hline Title of Article & \multicolumn{2}{|c|}{$\begin{array}{c}\text { Comparative Analysis of Recreational } \\
\text { Trends of University Students: The Case of } \\
\text { Çankırı }\end{array}$} & \\
\hline $\begin{array}{l}\text { Corresponding } \\
\text { Author }\end{array}$ & \multicolumn{2}{|c|}{$\begin{array}{l}\text { Özgür Burhan TiMUUR } \\
\text { Çankırı Karatekin Üniversitesi Orman Fakültesi Peyzaj Mimarlığı Bölümü, } \\
\text { e-posta: } \underline{\text { obtimur@karatekin.edu.tr }}\end{array}$} & \\
\hline $\begin{array}{l}\text { Received Date } \\
\text { Accepted Date }\end{array}$ & \multicolumn{2}{|l|}{$\begin{array}{l}08.05 .2020 \\
22.09 .2020 \\
\end{array}$} & \\
\hline Author / Authors & $\begin{array}{l}\text { Özgür Burhan TIMMUR } \\
\text { İbrahim AYTAŞ } \\
\text { Umut PEKİN TİMUR }\end{array}$ & $\begin{array}{l}\text { ORCID: 0000-0003-0626-3031 } \\
\text { ORCID: 0000-0002-0997-5862 } \\
\text { ORCID: 0000-0002-4644-610X }\end{array}$ & \\
\hline How to Cite & \multicolumn{2}{|c|}{$\begin{array}{l}\text { TİMUR, Ö.B., AYTAŞ, İ. \& PEKİN TİMUR, U. (2020). Üniversite Öğrencilerinin } \\
\text { Rekreasyonel Eğilimlerinin Karşılaştırmalı Analizi: Çankırı Örneği, Kent Akademisi, } \\
\text { Volume, 13, Issue 4, Pages, 417-430 }\end{array}$} & $\begin{array}{l}\text { Kent Akademisi } \\
\text { Urban Academy }\end{array}$ \\
\hline
\end{tabular}

\title{
Üniversite Öğrencilerinin Rekreasyonel Eğilimlerinin Karşılaştırmalı Analizi: Çankırı Örneği
}

\begin{abstract}
:
Comparative Analysis of Recreational Trends of University Students: The Case of Çankırı

Recreational areas in the cities, have important functions about supplying the psychological, physical and social needs of people, as well as re-establishing their relationships with nature in a concrete urban environment. In this research, some demographic characteristics of the students studying at Çankırı Karatekin University and the usage characteristics of all recreational areas of Çankırı city were analyzed. Within this scope, a survey study was conducted on 96 students. Descriptive statistics and frequency tables were used in the analysis of the obtained variables; Spearman's Correlation Analysis and Chi Square Test were used in determining the relationships between the variables. According to the results; it was found that low-income students had difficulty in participating recreational activities in terms of accessibility to the areas and duration of activity compared to high-income students, whereas high-income students were selective towards recreational areas. The results generally showed that; although the students did not find an adequate level for the recreation areas (\%52) and accessibility of these areas (\%76); the recreation areas met their requirements and they were moderately (\%50) satisfied with the areas. Through this study, suggestions were made to guide for the recreational applications at the urban scale as well as actions for the university campus in future.
\end{abstract}

KEYWORDS: Recreational trend, recreation, demand, Çankırı

\section{ÖZ:}

Kentlerde rekreasyon alanları, halkın psikolojik, fiziksel ve sosyal ihtiyaçlarının karşılanmasının yanı sıra betonlaşmış kent ortamında doğa ile ilişkisinin yeniden kurulmasında önemli işlevlere sahiptir. Bu araştırmada, Çankırı Karatekin Üniversitesi'nde öğrenim gören öğrencilerin bazı demografik özellikleri ile Çankırı kent genelindeki rekreasyon alanlarının kullanım özellikleri analiz edilmiştir. Bu kapsamda, üniversitede öğrenimine devam eden 96 öğrenci üzerinde anket çalışması gerçekleştirilmiştir. Elde edilen değişkenlerin analizinde tanımlayıcı istatistik ve frekans tabloları kullanılmış, değişkenler arasındaki ilişkilerin tespitinde ise Spearman Korelasyon Analizi ve Ki Kare Testi uygulanmıştır. Araştırma sonuçlarına göre; düşük gelirli öğrencilerin yüksek gelirli öğrencilere oranla, alana ulaşılabilirlik ve aktiviteye ayrılan süre bakımından rekreasyonel aktivitelere katılmakta zorluk çektiği, buna karşın, 
yüksek gelirli öğrencilerin rekreasyon alanlarına karşı seçici davrandığı tespit edilmiştir. Sonuçlar genel olarak; öğrencilerin rekreasyon alanlarını (\%52) ve bu alanlara ulaşılabilirliği yeterli düzeyde (\%76) bulmamalarına rağmen, rekreasyon alanlarının gereksinimlerini karşıladığını ve alanlardan orta düzeyde (\%50) memnun kaldıklarını ortaya

${ }^{1}$ Çankırı Karatekin Üniversitesi, Orman Fakültesi, Peyzaj Mimarlığı Bölümü, obtimur@karatekin.edu.tr

${ }^{2}$ Çankırı Karatekin Üniversitesi, Orman Fakültesi, Peyzaj Mimarlığı Bölümü, aytasibrahim@karatekin.edu.tr

${ }^{3}$ Çankırı Karatekin Üniversitesi, Orman Fakültesi, Peyzaj Mimarlığı Bölümü, umutpt@ gmail.com

koymaktadır. Bu çalışma yoluyla gerek kentsel ölçekteki rekreasyon çalışmalarını ve gerekse kampüse yönelik yapılacak çalışmaları yönlendirecek önerilerde bulunulmuştur.

ANAHTAR KELIMELER: Rekreasyonel eğilim, rekreasyon, talep, Çankırı

\section{GİRIŞ̧}

Rekreasyon alanları, kentin kalabalığından ve iş stresinden bir süre uzaklaşmak isteyen bireylerin boş zamanlarında vakit geçirebilecekleri açık ve kapalı mekânlardır. Bu alanlar bazen yeşil bir örtüyle kaplı olabildiği gibi bazen de bir tavan ya da yanal yüzeyle çevrili olabilir. Bireylerin sosyalleşme, huzuru yakalama, doğayı ve kendini keşfetme duygularını harekete geçirmelerine yardımcı olarak yaşam kalitelerini arttıran rekreasyon alanları, kent ölçeğinde başarılı bir şekilde projelendirilip hayata geçirildiğinde, huzurlu ve daha yaşanabilir kentler oluşturulabilmektedir. Özellikle sert zemin oranının yüksek olduğu kentlerde, açık ve kapalı mekânlardaki pasif ve aktif rekreasyonel etkinlikler, bireylerin psikolojik, fiziksel ve sosyal özelliklerinin iyileştirilmesi açısından önemli bir rol oynamaktadır. Bunun yanında, rekreasyon alanlarının kullanım kalitesi açısından geliştirilerek toplumun her kesimine hizmet verebilecek kapasiteye çıkarılması, kentsel yaşam kalitesinin ve dolayısıyla kent kalitesinin arttırılmasına doğrudan etki etmektedir.

Kentsel kaliteyi yükseltebilme özelliğine sahip nitelikli rekreasyon alanlarını oluşturabilmenin birinci ve en önemli adımı, bireylerin rekreasyon alanlarına olan talep ve eğilimlerinin ölçülmesidir. Rekreasyonel talep ve eğilimin belirlenmesine yönelik çalışmalar, rekreasyonel alanların kapasitelerinin, sayılarının, kent içi dağılımlarının, birbirleri arasındaki mesafelerin ve rekreasyonel aktivite çeşitlerinin tespitinde son derece önemli bir basamağ teşkil etmektedir. Konuya ilişkin literatür incelendiğinde; kent halkının rekreasyonel eğilim ve taleplerinin belirlenmesine yönelik (Yılmaz vd., 2003; Jim ve Chen, 2006; Kaya, 2007; Ekal, 2010; Talay vd., 2010; Sağlık ve Kelkit, 2014; Yalçınyavuz, 2015; Şişman ve Özyavuz, 2016; Yalçıyavuz ve Yılmaz, 2016) ve üniversite öğrencilerinin rekreasyonel eğilim ve taleplerinin belirlendiği çalışmaların (Bryant vd., 1995; Johnson vd., 2001; Mansuroğlu, 2002; Önder, 2003; Lindsay ve Sessoms, 2006; Kiper, 2009; Kuş Şahin vd., 2011; Çoruh ve Karaküçük, 2014) bulunduğu ancak değerlendirmelerin Ki Kare ile sınırlı kaldığı görülmüştür.

Çankırı kenti sosyo-ekonomik gelişmişlik sırasında Türkiye'de 54. sırada bulunmaktadır (URL-1). Kentin daha tercih edilebilir ve yaşanabilir bir kent haline gelmesi için, kentin sosyo-ekonomik gelişmik düzeyinin arttırılması gerekmektedir. Sosyo-ekonomik gelişmişlik düzeyinin arttırılması için ise, kentin sınai, zirai ve ticari faaliyetlerindeki gelişiminin yanında, sosyo-kültürel anlamda bir gelişmeye de ihtiyaç duyulmaktadır. Sosyo-kültürel gelişimin sağlanmasında, kent içi rekreasyonel faaliyetlerin kalitesinin arttırılması kritik bir konu olarak karşımıza çıkmaktadır. Bireyin ve toplumun rekreasyonel ihtiyaçlarına doğru zamanda, doğru yerde ve uygun rekeasyonel faaliyet türleriyle cevap vererek hem kent halkının sosyal refah düzeyi arttırılabilir hem de kentin yaşanabilirlik düzeyi üst seviyelere çıkarılabilir. Bu noktada 2007 yılında Çankırı Karatekin Üniversitesi'nin kurulması, kentin ekonomik ve sosyo-kültürel açıdan gelişimi için son derece önemlidir. 2017 yılı itibariyle 13.900 öğrenciye sahip olan üniversitede 8 fakülte, 5 meslek yüksekokulu ve 1 yüksekokul bulunmaktadır. Çankırı'da öğrenim gören öğrenciler, boş zamanlarını kentte sınırlı imkânlara sahip rekreasyonel alanlarda geçirmektedir. Rekreasyon alanlarındaki kafeterya, restoran, spor alanları gibi aktif kullanımların niteliksiz ve az sayıda olması öğrencilerin en çok dile getirdiği problemler arasındadır. Ayrıca bu rekreasyon alanları yeşil alan miktarı bakımından yetersiz alanlardır (Bilgili, 2013).

$\mathrm{Bu}$ araştırmada Çankırı Karatekin Üniversitesi’nde öğrenimine devam eden üniversite öğrencilerinin cinsiyet, yaş, öğrenim gördüğü fakülte, ikamet durumu, büyüdüğü yer, ve ailenin aylık geliri gibi sosyo-demografik özellikleri ile kentin tüm rekreasyon alanlarının kullanım özellikleri analiz edilerek, öğrencilerin rekreasyon alanlarına eğilimleri, rekreasyonel etkinliklere katılım düzeyi ve rekreasyonel taleplerinin belirlenmesi amaçlanmıştır. Böylece, gerek 
kentsel ölçekteki rekreasyon çalışmalarını ve gerekse kampüse yönelik yapılacak çalışmaları yönlendirecek önerilerde bulunulmuştur.

\section{MATERYAL ve YÖNTEM}

\subsection{Materyal}

Çalışma, Üniversite öğrencilerinin Çankırı kent merkezindeki tüm rekreasyon alanlarını kullandığı varsayılarak kent genelinde yürütülmüştür (Şekil 1).

Çankırı İli (Şekil 1); İç Anadolu Bölgesinin kuzeybatısındadır. İlin yüzölçümü 2210 km², denizden yüksekliği 736 metredir. İç Anadolu Bölgesi'nin karasal iklim özelliklerinin egemen olması nedeniyle ilde yazlar sıcak ve kurak, kışlar soğuk ve sert geçmektedir (Anonim, 2010). Ortalama sıcaklık $11,3^{\circ} \mathrm{C}$ olup, en çok yağışın düştüğü mevsim ise ilkbahardır. En fazla yağış Mayıs, en az yağış ise Eylül ayında düşmekte olup merkez ilçede hâkim rüzgâr yönü kuzeybatıdır (Tuna, 2010). Özellikle kışları ilde sert ve soğuk bir iklim yaşanması öğrencilerin kış aylarında kapalı mekânlara olan ihtiyacını arttırmaktadır.

Çankııı İlinin ulaşması gereken yeşil alan miktarı 69 ha. iken mevcut rekreasyon alanlarının kent merkezindeki miktarı ise 6.6 ha.'dır. Bunun yaklaşı \% 42'sini genellikle kentli tarafindan aktif olarak kullanılmayan şehir koruluğu oluşturmaktadır. Bu durum, mevcut rekreasyon alanlarının olması gerekenin oldukça altında olduğunu göstermektedir (Bilgili, 2013).

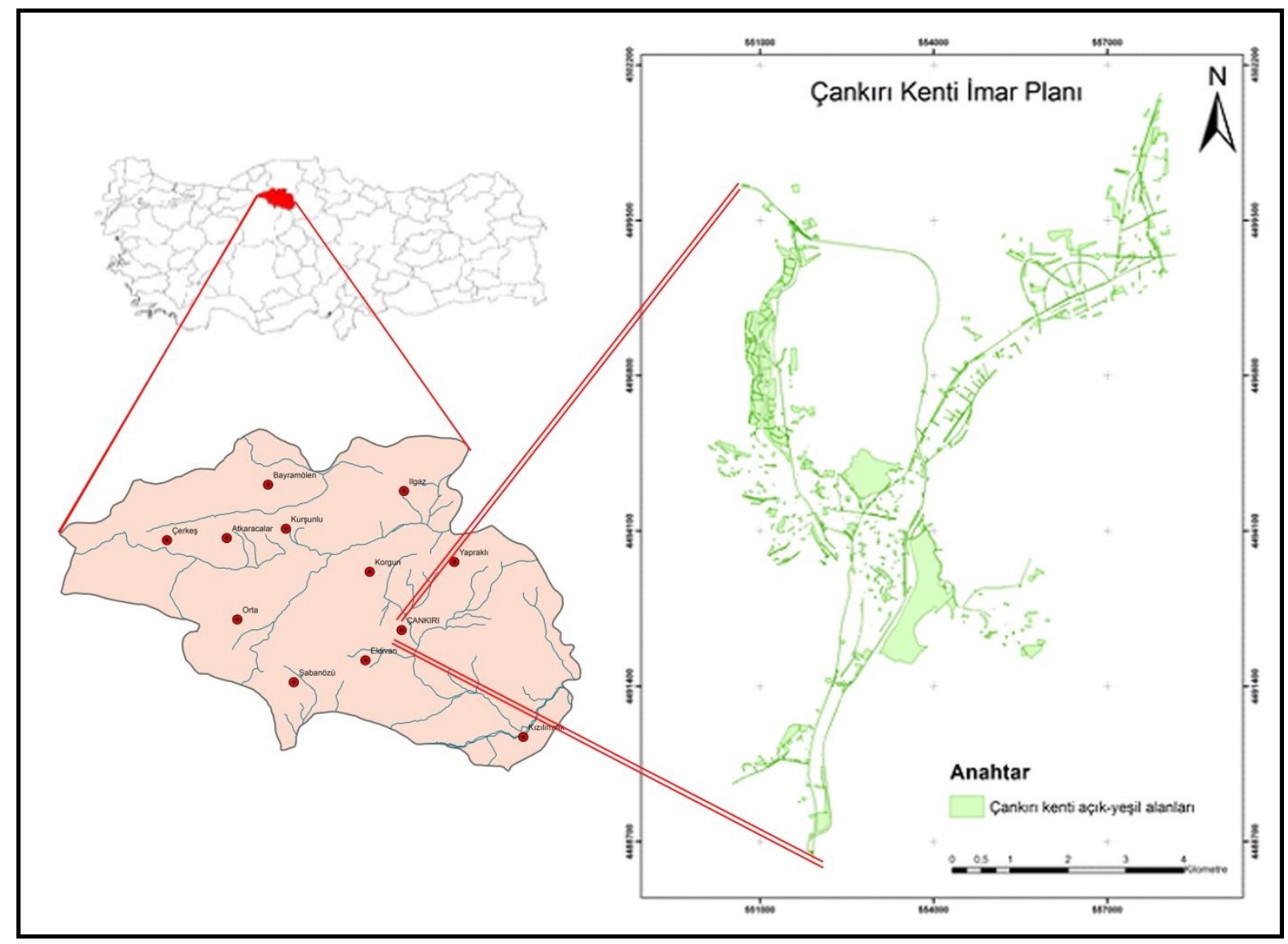

Şekil 1. Çalışma alanı

Çalışma, öğrencinin hangi fakültede olduğu gözetilmeksizin tüm üniversite öğrencileri için gerçekleştirilmiştir. Araştırmanın Çankırı kent merkezindeki alanlarda yapılmasının sebebi, veriye ulaşmadaki kolaylık ve rekreasyon 
alanlarının yetersizliği nedeniyle bu alanların halk ve öğrenciler tarafindan yoğun olarak kullanılmasıdır. Bunun yanında, literatür taraması kapsamında çeşitli akademik dergi, makale, tez ve kitaplardan faydalanılmıştır. Verilerin elde edilmesinde anketlerden, verilerin analizinde ise SPSS 20.0 İstatistik Paket Programı'ndan yararlanılmıştır.

Çalışmada, Çankııı kenti rekreasyon alanlarını kullanan ve Çankırı Karatekin Üniversitesi'nde okuyan lisans öğrencileri örneklem küme olarak belirlenmiştir.

\subsection{Yöntem}

Araştırma üç aşamalı bir yöntem ile yürütülmüştür. İlk aşama; araştırmanın amacına yönelik literatür taraması, anket formları hazırlama ve bu anketleri uygulama çalışmalarını içermektedir. II. aşamada anketlere yönelik istatistik analizleri ve testler yapılmıştır. Üçüncü ve son aşamada ise analiz sonuçlarına göre değerlendirme ve önerilere yer verilmiştir.

İlk aşamada konuya ilişkin literatür incelenmiş ve akademik anlamda literatürün istatistiki yöntem bakımından eksikliği (bkz. Giriş bölümü: çalışmalar yöntem bakımından Ki-Kare ile sınırlı kalmıştır) ortaya konulmuştur. Bu literatürle birlikte, anket formunun hazırlanmasında çeşitli akademik çalışmalardan (Bell, 1997; Önder, 2003; Yılmaz vd., 2003; Kiper, 2009) yararlanılmıştır. Anket formu iki bölümden oluşmaktadır. Birinci bölüm kentin rekreasyon alanlarını kullananların sosyo-demografik özelliklerini ifade eden; cinsiyet, yaş, öğrenim gördüğü fakülte, ikamet durumu, büyüdüğ̈̈ yer, ailenin aylık geliri, kullandığı rekreasyonel alanlar, rekreasyonel alanlarda gerçekleştirdiği faaliyet tipleri, rekreasyonel alanlara ulaşım durumu, katıldığı etkinlik tipi gibi kapalı uçlu soruları içermektedir. İkinci bölüm ise; bu rekreasyonel alanların kullanım özelliklerini ifade eden ve daha çok kullanıcının alana yönelik psikolojik eğilim ve durumunu ortaya koyan 10 adet kapalı uçlu sorudan (rekreasyonel alanlara olan ihtiyacın karşılanma düzeyi, rekreasyon alanlarından duyulan memnuniyet düzeyi, rekreasyonel alanların yeterlilik düzeyi, rekreasyonel alanların önemi, rekreasyonel alanlara ulaşılabilirlik düzeyi vb.) oluşmaktadır.

Çalışma kapsamında hazırlanan anketler Çankırı Karatekin Üniversitesi öğrencileri tarafından uygulanmıştır. Ankete toplam 96 kişi katılmış olup, anketler 2017 yılının Mayıs ayında yüz yüze görüşme şeklinde ve 10'ar dakikalık süreler içerisinde uygulanmıştır. Örnekleme türü olarak basit tesadüfi örnekleme tercih edilmiştir. Örneklem büyüklüğünün belirlenmesinde ise; anketlerin kategorik veri içermesi nedeniyle gerçekleşme olasillğ olasılığının (q) eşit olduğu ( $\mathrm{p}=0,5 ; \mathrm{q}=0,5)$ varsayılmıştır. Üniversitenin toplam öğrenci sayısının 13.900 olduğundan hareketle ve \%10 hata payı ile ( $(\mathrm{d}=0,1)$, örneklem hacmi 96 olarak hesaplanmıştır (Yazıcıoğlu ve Erdoğan, 2004).

“Ailenin aylık geliri” ve "öğrencinin aylık geliri” sorularına verilen cevaplarda artan değer bulunmakta olup, bu iki soruda 3 noktalı likert ölçeği kullanılmış ve verilen yanıtlar istatistik programına işlenmiştir. Yaş değişkeni de artan değere sahip olmakla birlikte, ankete katılan öğrencilerin tamamının tek bir yaş grubuna girmesi nedeniyle "yaş" değişkeni likert ölçeğiyle değerlendirilememiştir. "Ailenin aylık geliri” değişkeni için verilen yanıtlar, programa "1000-2500 TL" ise "1", "2500-4000 TL" ise "2", "4000 TL ve üzeri” ise "3" olarak kodlanmıştır. "Öğrencinin aylık geliri” değişkeni için verilen yanıtlar, programa "400-800 TL" ise "1", "800-1200 TL" ise "2", "1200-2000 TL" ise "3" olarak işlenmiştir.

Öte yandan, rekreasyonel alanların kullanım özelliklerine ve kullanıcının alana yönelik psikolojik eğilim ve durumuna ilişkin sorularda 3 noktalı likert ölçeği (hayır, kararsızım, evet) kullanılmış olup, verilen cevaplar istatistik programına "hayır" ise "1", "kararsızım" ise "2", "evet" ise " 3 " olarak kodlanmıştır. Gereksinimlerin karşılanması, memnuniyet düzeyi ve rekreasyon alanlarının önemine ilişkin sorularda ise daha detaylı veri elde etmek amacıyla 5 noktalı likert ölçeği (kesinlikle katılmıyorum, katılmıyorum, fikrim yok, katılıyorum, kesinlikle katılıyorum) tercih edilmiş olup, verilen cevaplar istatistik programına "kesinlikle katılmiyorum" ise "1", "katılmıyorum" ise "2", "fikrim yok" ise "3", "kat1lyyorum" ise "4" ve "kesinlikle katıllyorum" ise "5" olarak işlenmiştir.

İkinci aşama olarak; verilerin analiz edilmesi sürecinde öncelikle rekreasyonel alan kullanıcılarının özellikleri, istatistik programında kişi sayısı ve yüzdelik dağılımlar bakımından incelenmiştir. Sonrasında; öğrencilerin Çankırı kenti rekreasyon alanlarına eğilimlerini belirli ana başlıklar (faktörler) altında irdelemek ve tartışmak amacıyla Faktör Analizi kullanılmıştır. Bu istatistik yönteminin tercih edilmesinin nedeni, çok sayıdaki anket sorusunun ayrı ayrı değerlendirilmesinin ya da aralarındaki ilişkilerin tespitinin istatistiksel anlamda güç oluşudur (Noe ve Uysal, 1997; Özdamar, 2013). Ayrıca, gruplama sonucunda elde edilen faktörlerin güvenilirliğini/tutarlılığını test etmek için Güvenilirlik Analizi (Özdamar, 2013) yapılmıştır. Daha sonra; belirlenen rekreasyonel kullanım faktörlerinin bazı tanımlayıcı istatistik değerleri verilmiş ve verilen cevaplara göre yüzdelik dağılımları analiz edilmiştir. Sonrasında bu 
faktörlerin arasındaki istatistiksel ilişkiler Spearman Korelasyon Analizi ile incelenmiştir. Kullanıcı özellikleri ile rekreasyon alanlarının kullanım özellikleri arasındaki ilişkiler ve alan kullanım özelliklerinin kendi içindeki ilişkiler Ki Kare istatistik yöntemi kullanılarak analiz edilmiştir. Analizlerde parametrik olmayan yöntemlerin kullanılmasının temel sebebi verilerin kategorik değişkenler içermesi ve normal dağılım göstermemesidir. Verilerin normallik testinin gerçekleştirilmesinde Kolmogorov-Smirnov Testi (one sample K-S) kullanılmış ve \%95 güven düzeyinde verilerin normal dağılım göstermediği tespit edilmiştir $(\mathrm{p}<0,05)$. Bu nedenle, çalışmada parametrik olmayan istatistik yöntemlerinden olan Spearman Korelasyon Analizi ve Ki Kare Analizi tercih edilmiştir. Ayrıca, yapılan tüm analizlerde önem derecesi (p) < 0,05 olarak alınmıştır (Özdamar, 2013).

Son aşamada, yani üçüncü aşamada gerek kentsel ölçekteki rekreasyon çalışmalarını ve gerekse kampüse yönelik yapılacak çalışmaları yönlendirecek önerilerde bulunulmuştur.

\section{BULGULAR ve TARTIŞMA}

Kullanıcı özelliklerine yönelik yapılan yüzdesel analize göre; kullanıcıların \%51'inin erkek, \%49'unun kadın olduğu ve tamamının öğrenci olması nedeniyle yaşlarının 18-25 grubunda olduğu görülmüştür. Öğrencilerin önemli bir bölümü $(\% 60,4)$ evde ikamet etmektedir (Tablo 1).

Tablo 1. Kullanıcı özelliklerine ilişkin frekans tablosu

\begin{tabular}{|c|c|c|c|}
\hline Kullanıcı Özellikleri & Gruplar & Gruplardaki Kişi Sayısı (n) & $\begin{array}{l}\text { Gruplardaki Yüzdelik } \\
\text { Dağılımlar (\%) }\end{array}$ \\
\hline \multirow{2}{*}{ Cinsiyet } & Erkek & 49 & 51,0 \\
\hline & Kadın & 47 & 49,0 \\
\hline \multirow{2}{*}{ Yaş } & $18-25$ & 95 & 99,0 \\
\hline & $26-40$ & 1 & 1,0 \\
\hline \multirow{6}{*}{ Öğrenim gördüğü fakülte } & Güzel Sanatlar Fakültesi & 39 & 40,6 \\
\hline & İktisadi Bilimler Fakültesi & 19 & 19,8 \\
\hline & Meslek Yüksek Okulu & 17 & 17,7 \\
\hline & Mühendislik Fakültesi & 4 & 4,2 \\
\hline & Orman Fakültesi & 7 & 7,3 \\
\hline & Fen Edebiyat Fakültesi & 10 & 10,4 \\
\hline \multirow{3}{*}{ İkamet durumu } & $\mathrm{Ev}$ & 58 & 60,4 \\
\hline & Yurt & 16 & 16,7 \\
\hline & Apart & 22 & 22,9 \\
\hline \multirow{3}{*}{ Büyüdüğü yer } & Köy & 10 & 10,4 \\
\hline & Kasaba & 24 & 25,0 \\
\hline & Şehir & 62 & 64,6 \\
\hline \multirow{3}{*}{ Ailenin aylık geliri } & $1000-2500 \mathrm{TL}$ & 24 & 25,0 \\
\hline & $2500-4000 \mathrm{TL}$ & 66 & 68,7 \\
\hline & 4000 TL ve üzeri & 6 & 6,3 \\
\hline \multirow{3}{*}{ Öğrencinin aylık geliri } & $400-800 \mathrm{TL}$ & 59 & 62,8 \\
\hline & 800-1200 TL & 33 & 35,1 \\
\hline & $1200-2000 \mathrm{TL}$ & 2 & 2,1 \\
\hline \multirow{3}{*}{ Rekreasyonel faaliyet alanları } & Açık doğal alanlar & 60 & 62,5 \\
\hline & Kapalı alanlar & 8 & 8,3 \\
\hline & Teknolojik faaliyet alanları & 28 & 29,2 \\
\hline \multirow{4}{*}{ Rekreasyonel faaliyet tipi } & Go-kart & 36 & 37,5 \\
\hline & Yüzme & 32 & 33,3 \\
\hline & Lunaparkta eğlenme & 25 & 26,0 \\
\hline & Diğer & 3 & 3,2 \\
\hline \multirow{3}{*}{ Ulaşım durumu } & Toplu taşıma & 35 & 36,5 \\
\hline & Kişisel araç & 32 & 33,3 \\
\hline & Yaya & 29 & 30,2 \\
\hline \multirow{5}{*}{$\begin{array}{l}\text { Alanların kullanım-hizmet } \\
\text { durumu }\end{array}$} & Kullanışlı & 22 & 22,9 \\
\hline & Kullanışsız & 54 & 56,3 \\
\hline & Temiz, güzel ve yeşil bir çevre & 3 & 3,1 \\
\hline & Kirli & 5 & 5,2 \\
\hline & _Gürültülü & 10 & 10,4 \\
\hline
\end{tabular}




\begin{tabular}{llll}
\hline & Diğer & 2 & 2,1 \\
\hline \multirow{4}{*}{ Kültürel-sosyal etkinlik türü } & Sinema & 56 & 58,2 \\
& Tiyatro & 30 & 31,3 \\
& Sergi-fuar & 4 & 4,2 \\
& Söyleşi & 6 & 6,3 \\
\hline \multirow{5}{*}{ Sportif etkinlik alanı } & Basketbol sahasi & 23 & 24,0 \\
& Yüzme havuzu & 54 & 56,2 \\
& Kapalı spor salonu & 13 & 13,5 \\
& Tenis kortu & 6 & 6,3 \\
\hline \multirow{5}{*}{ Doğaya yönelik etkinlik alanı } & Bisiklet yolu & 37 & 38,5 \\
& Koşu-yürüme pisti & 40 & 41,7 \\
& Botanik bahçesi & 12 & 12,5 \\
& Piknik alanı & 7 & 7,3 \\
\hline \multirow{2}{*}{ Diğer etkinlikler } & Dans etkinlikleri & 33 & 34,4 \\
& Müzikal etkinlikler & 40 & 41,6 \\
& Yabancı dil etkinlikleri & 23 & 24,0 \\
\hline
\end{tabular}

Ayrıca Tablo 1 incelendiğinde, öğrencilerin büyük bir kısmının $(\% 64,6)$ şehirlerde büyüyüp yaşadığı, aylık gelirinin 400-800 TL arasında olduğu $(\% 62,8)$, genellikle açık-yeşil ve doğal alanları tercih ettikleri $(\% 62,5)$ anlaşılmaktadır. Rekreatif faaliyetlerden go-kart ve yüzme faaliyetlerini daha çok tercih eden öğrenciler, rekreasyon alanlarını baskın oranda kullanışsız bulmaktadır (\%56,3). Bunun yanında, öğrenciler kültürel etkinlikler grubundan "sinema", sportif etkinlikler grubundan "yüzme" ve diğer etkinlikler grubundan "dans ile müzikal etkinlikleri" daha fazla tercih etmektedir. Son olarak öğrenciler doğaya yönelik etkinlik alanlarından "bisiklet yolu $(\% 38,5)$ " ve "koşu-yürüyüss pisti $(\% 41,7)$ " alanlarını daha yoğun biçimde kullanmak istemektedir.

Kullanıcıların rekreasyonel alanlara eğilimini ve alanların kullanım özelliklerini belirleyen 10 adet soru Faktör analizine tabi tutulmuştur (Tablo 2). Analiz sonuçlarına göre 3 soru grup dışı kalmış ve kalan 7 soruyu \% 57,9 varyansla açıklayan 2 faktör tespit edilmiştir. Ayrıca, faktörler için güvenilirlik analizi yapılmış ve Faktör 1 (F1) için Cronbach's alpha değeri 0,864, Faktör 2 (F2) için Cronbach's alpha değeri 0,377 olarak belirlenmiştir (Cronbach's Alpha Faktör $\geq \%$ 60). Bu sonuçlara göre; F1 yüksek derecede güvenilir iken, F2 ise güvenilir değildir. Ancak, F2'nin sonuçlara kritik derecede etki ettiği düşünüldüğünden, bu faktör değerlendirmeye alınmıştır. Buna ek olarak, faktörlerin her biri, sahip olduğu soruların ortak özelliklerinden yola çıkılarak isimlendirilmiştir. Buna göre; F1 "Gereksinimlerin karșılanması ve memnuniyet düzeyi" ve F2 ise "Rekreasyonel alanların yeterlilik düzeyi" olarak adlandırılmıştır. F1, 3 adet soruyu içermekte olup, \% 34,6 varyansla açıklanmaktadır. F2, 4 adet soruyu içermekte olup, \% 23,3 varyansla açıklanmaktadır (Tablo 2). Alınan sonuçlar anlamlı olup $(\mathrm{p}=0,000<0,05)$, tutarlılık göstermektedir (KMO test $=0,682)$.

Diğer taraftan, belirlenen bu iki faktöre ek olarak, faktör analizi sonucunda grupların dışında kalan diğer 3 soru, her biri ayrı birer faktör olacak şekilde adlandırılmıştır. Bu soruların faktör olarak değerlendirilmesinin sebebi, soruların çalışmanın sonuçlarını doğrudan etkileyecek öneme sahip olduğu düşüncesidir. Ayrıca, kullanıcı özelliklerinden “ ailenin aylık geliri", "öğrencinin aylık geliri” ve "rekreasyonel aktiviteye ayrılan süre" soruları da her biri ayrı faktör olarak adlandırılarak değerlendirmeye alınmıştır. Bu 3 sorunun değerlendirmeye alınma sebebi ise; sorulara verilen cevapların artan özellikte olması nedeniyle korelasyon analizlerinde kullanılabilir olması ve kullanıcı özelliklerinin rekreasyonel eğilimlere ne derece etki ettiğini tespit etme hedefleridir (Tablo 2).

Tablo 2. Çankırı kenti rekreasyonel eğilim faktörleri

\begin{tabular}{lll}
\hline Rekreasyonel Ĕ̆ilim Soruları & F1 & F2 \\
\hline Rekreasyon alanları diğer öğrencilerin gereksinimlerini karşılayabiliyor mu? & 0,891 & - \\
Mevcut rekreasyon alanlarından memnun musunuz? & 0,883 & - \\
Rekreasyon alanları sizin gereksinimlerinizi karşılıyor mu? & 0,869 & - \\
Çankırı şehrinde yer alan rekreasyon alanları ihtiyacı karşılıyor mu? & - & 0,759 \\
Sizce Çankırı için rekreasyon alanları yeterli mi? & - & 0,754 \\
Sizce Türkiye rekreasyonel aktivite açısından yeterli midir? & - & 0,557 \\
Sizce Üniversite'nin rekreasyon alanları yeterli midir? & - & 0,397 \\
\hline
\end{tabular}


VARYANS \%

$34,60 \%$

$23,30 \%$

CRONBACH'S ALPHA $\alpha$

0,864

0,377

F1: Gereksinimlerin karşılanması ve memnuniyet düzeyi, F2: Rekreasyonel alanların yeterlilik düzeyi

Böylece korelasyon ve Ki kare analizlerine dahil olacak toplamda 8 adet faktör belirlenmiştir. Bu 8 faktöre ilişkin verilen cevaplara yönelik yüzdelik dağılımlar ve tanımlayıcı istatistik değerleri hesaplanmıştır (Tablo 3).

Tablo 3. Rekreasyon alanlarının kullanım faktörlerine ilişkin frekans ve tanımlayıcı istatistik tablosu

\begin{tabular}{|c|c|c|c|}
\hline $\begin{array}{l}\text { Rekreasyon Alanlarının Kullanım } \\
\text { Faktörleri }\end{array}$ & Gruplar & $\begin{array}{l}\text { Gruplardaki Yüzdelik } \\
\text { Dağılımlar (\%) }\end{array}$ & $\begin{array}{l}\text { Tanımlayıcı İstatistik } \\
\text { Değerleri }\end{array}$ \\
\hline $\begin{array}{l}\text { Gereksinimlerin karşılanması ve } \\
\text { memnuniyet düzeyi (F1) }\end{array}$ & $\begin{array}{l}\text { Kesinlikle katılmiyorum } \\
\text { Katılmiyorum } \\
\text { Fikrim yok } \\
\text { Katıliyorum } \\
\text { Kesinlikle katıliyorum }\end{array}$ & $\begin{array}{l}15,6 \\
18,8 \\
15,6 \\
14,6 \\
35,4\end{array}$ & $\begin{array}{l}\mathrm{N}=96 \\
\text { Min. }=1 \text { Max. }=5 \\
\bar{X}=\mathbf{3 , 3 5} \\
\text { Std. } \text { S. }=1,508\end{array}$ \\
\hline $\begin{array}{l}\text { Rekreasyonel alanların yeterlilik düzeyi } \\
\text { (F2) }\end{array}$ & $\begin{array}{l}\text { Hayır } \\
\text { Kararsızım } \\
\text { Evet }\end{array}$ & $\begin{array}{l}52,0 \\
43,8 \\
4,2\end{array}$ & $\begin{array}{l}\mathrm{N}=96 \\
\text { Min. }=1 \text { Max. }=3 \\
\bar{X}=\mathbf{1 , 5 2} \\
\text { Std. S. }=0,580\end{array}$ \\
\hline Ulaşılabilirlik düzeyi (F3) & $\begin{array}{l}\text { Hayır } \\
\text { Kararsızım } \\
\text { Evet }\end{array}$ & $\begin{array}{l}76,0 \\
16,7 \\
7,3\end{array}$ & $\begin{array}{l}N=96 \\
\text { Min. }=1 \text { Max. }=3 \\
\bar{X}=1,31 \\
\text { Std. S. }=0,604\end{array}$ \\
\hline Rekreasyonel alanların önemi (F4) & $\begin{array}{l}\text { Kesinlikle katılmiyorum } \\
\text { Katılmiyorum } \\
\text { Fikrim yok } \\
\text { Katıliyorum } \\
\text { Kesinlikle katıliyorum }\end{array}$ & $\begin{array}{l}12,5 \\
6,3 \\
11,5 \\
12,5 \\
57,2\end{array}$ & $\begin{array}{l}\mathrm{N}=96 \\
\text { Min. }=1 \text { Max. }=5 \\
\bar{X}=3,96 \\
\text { Std. } S .=1,443\end{array}$ \\
\hline Ailenin aylık geliri (F5) & $\begin{array}{l}1000-2500 \mathrm{TL} \\
2500-4000 \mathrm{TL} \\
4000 \mathrm{TL} \text { ve üzeri }\end{array}$ & $\begin{array}{l}25,0 \\
68,7 \\
6,3\end{array}$ & $\begin{array}{l}\mathrm{N}=96 \\
\text { Min.=1 Max.=3 } \\
\bar{X}=1,81 \\
\text { Std. S. }=0,529\end{array}$ \\
\hline Öğrencinin aylık geliri (F6) & $\begin{array}{l}400-800 \mathrm{TL} \\
800-1200 \mathrm{TL} \\
1200-2000 \mathrm{TL}\end{array}$ & $\begin{array}{l}62,8 \\
35,1 \\
2,1\end{array}$ & $\begin{array}{l}\mathrm{N}=94 \\
\text { Min.=1 Max.=3 } \\
\bar{X}=1,39 \\
\text { Std. S. }=0,533\end{array}$ \\
\hline Rekreasyonel aktiviteye ayrilan süre (F7) & $\begin{array}{l}0-2 \text { saat } \\
2-4 \text { saat } \\
4-6 \text { saat } \\
6-8 \text { saat } \\
8 \text { saat ve üzeri }\end{array}$ & $\begin{array}{l}25,0 \\
45,8 \\
22,9 \\
2,1 \\
4,2\end{array}$ & $\begin{array}{l}N=96 \\
\text { Min. }=1 \text { Max. }=5 \\
\bar{X}=2,15 \\
\text { Std. } S .=0,962\end{array}$ \\
\hline $\begin{array}{l}\text { Geldiği yerdeki imkânları Çankırı'da } \\
\text { bulabilme durumu (F8) }\end{array}$ & $\begin{array}{l}\text { Hayır } \\
\text { Kararsızım } \\
\text { Evet }\end{array}$ & $\begin{array}{l}90,6 \\
6,3\end{array}$ & $\begin{array}{l}\mathrm{N}=96 \\
\text { Min.=1 Max.=3 } \\
\bar{X}=1,13 \\
\text { Std. S. }=0,417\end{array}$ \\
\hline
\end{tabular}

Analiz sonuçlarına göre; gereksinimlerin karşılanması ve memnuniyet düzeyi (F1) bakımından rekreasyonel alan kullanıcılarının belli bir tatmin düzeyine ulaştığı görülmektedir ( = 3,35). Bunun yanında, kullanıcılar rekreasyon alanlarını oldukça önemli görmekte $(\mathrm{F} 4 ;=3,96)$ buna karşın, alanları yeterli bulmamaktadır $(\mathrm{F} 2 ;=1,52)$. Öğrenciler, Çankırı kent merkezindeki rekreasyon alanlarına ulaşımı yetersiz bulmakta $(\mathrm{F} 3 ;=1,31)$ ve geldiği (büyüdüğü) yerdeki imkânları Çankırı'da bulamamaktadır $(\mathrm{F} 8 ;=1,13)$. Ayrıca, aylık geliri genellikle düşük olan öğrencilerin yarıya yakını $(\% 45,8)$ rekreasyonel aktivitelere $2-4$ saat süre $(\mathrm{F} 7 ;=2,15)$ ayırmaktadır $($ Tablo 3$)$.

Belirlenen 8 Faktör, korelasyon analizine tabi tutulmuş ve bu faktörler arasındaki anlamlı ilişkiler incelenmiştir (p $<$ 0,05). Analiz sonuçlarına göre; F1 ile F5 ve F6 arasında pozitif yönde, yüksek önem düzeyinde ilişki tespit edilmiştir $(\mathrm{p}=0,000<0,05 ; \mathrm{r}=0,366 ; \mathrm{r}=0,392)$. Diğer bir ifadeyle, öğrencilerin ve ailelerinin aylık geliri arttıkça, rekreasyon alanlarından gereksinimlerini karşılama ve memnuniyet düzeyleri de artmaktadır (Tablo 4). Bu sonuç, geliri 
diğerlerine nazaran daha yüksek olan öğrencilerin katıldıkları rekreasyonel aktivite çeşidinin fazla olmasıyla açıklanabilir. Nitekim, Kuş Şahin vd. (2011) çalışmasında, öğrencilerin ekonomik imkânlarının kısıtlı olmasının fazla ücret gerektiren bazı rekreasyonel aktivitelere katılımı güçleştirdiğini ve bu nedenle öğrencilerin birçok aktiviteyi gerçekleştiremediklerini ifade etmektedir.

Buna karşın, F1 ile F3 ve F7 arasında negatif yönde, yüksek önem düzeyinde ilişki olduğu belirlenmiştir $(\mathrm{p}<0,01 ; \mathrm{r}=$ $-0,374 ; r=-0,274)$. Yani öğrencilerin rekreasyon alanlarına ulaşılabilirlik düzeyi ve rekreasyonel aktivitelere ayırdıkları süreler azaldıkça, gereksinimlerini karşılama ve memnuniyet düzeyleri artmaktadır. Bu duruma istinaden, sonucun tam tersi yönde olması beklenebilir. Ancak, böyle bir sonucun ortaya çıkmasında, öğrencilerin erişilmesi daha zor alanlarda daha az sürede daha kaliteli zaman geçirmek istemeleri etkili olabilir. Alınan bir önceki sonuç da bu olguyu desteklemektedir. Bu durumda, bir önceki sonuçla da kıyas edildiğinde, yüksek gelirli öğrencilerin düşük gelirlilere oranla daha uzak yerlere gidip daha yüksek ücretler ödeyerek rekreasyonel aktivite çeşitliliğini ya da kalitesini arttırmaları sonucunda, kısa sürelerde daha fazla rekreasyon ihtiyacını karșılama ve yaptıkları aktivitelerden daha çok memnun olma arayışına girdikleri söylenebilir. Karaşah'ın (2017) çalışmasında da benzer bir durumun olduğu ve sonuçlarının bu çalışmayla paralellik gösterdiği söylenebilir. Ulaşılabilirlik düzeyi konusunda tersi bir görüş olarak Kuş Şahin vd. (2011), ulaşılabilirliğin azalmasıyla birlikte, ekonomik kısıtlara bağlı olarak öğrencilerin rekreasyonel aktivitelerinin önemli ölçüde azaldığını belirtmektedir. Ancak, bu tespit, bu çalışma için, düşük gelirli öğrenciler ile sınırlandırılabilir. Çünkü yüksek gelirli öğrenciler için tersi bir durum söz konusudur. Korelasyon analizi sonuçlarına bakıldığında ise; yapılan bu çıkarımı doğrulayan ve destekleyen bir biçimde, alanlara ulaşılabilirliğin artmasıyla birlikte rekreasyonel aktivitelere ayrılan sürenin de arttığı görülmektedir $(p<0,05 ; \mathrm{r}=$ 0,431). Aynı şekilde, alanlara ulaşılabilirlik arttıkça öğrencilerin geldiği yerdeki imkânları Çankırı'da bulabilme durumu da artmaktadır ( $\mathrm{p}<0,05 ; \mathrm{r}=0,213)$. Alınan bu iki sonuç birbiriyle paralellik göstermektedir. Bu durum, belli bir ölçüde Çankırı rekreasyon alanlarının yeterlilik düzeyi ile açıklanabilir. Çünkü, öğrencilerin rekreasyon alanlarına ulaşılabilirliği arttıkça, rekreasyonel alanların yeterlilik düzeyi de artmaktadır $(p=0,005<0,05 ; \mathrm{r}=0,281)$. Diğer bir deyişle, alanların ulaşılabilirlik düzeyi arttıkça yeterlilik düzeyi de artmakta ve bu da rekreasyonel aktivitelere ayrılan süreleri arttırarak öğrencilerin geldikleri yerdeki imkânları Çankırı'da bulabilmelerini sağlamaktadır (Tablo 4).

Ek olarak, öğrenci ailesinin aylık geliri arttıkça, öğrencinin aylık geliri ve rekreasyonel alanlara verdiği önem de paralel olarak artmaktadır $(\mathrm{p}<0,05 ; \mathrm{r}=0,392 ; \mathrm{r}=0,272)$. Bu sonuç, bireylerin ekonomik durumundaki artışın aynı ölçüde rekreasyonel alanlara bakış açısını da geliştirdiğini göstermektedir (Tablo 4). Kiper'in (2009) çalışmasında da benzer şekilde gelir düzeyinin düşük olmasının rekreasyonu olumsuz yönde etkilediği ifade edilmektedir.

Tablo 4. Rekreasyonel kullanım faktörleri arasındaki anlamlı ilişkiler

\begin{tabular}{|c|c|c|c|c|c|c|c|c|}
\hline $\begin{array}{c}\text { REKREASYONEL } \\
\text { KULLANIM } \\
\text { FAKTÖRLERİ }\end{array}$ & & F2 & F3 & F4 & F5 & F6 & F7 & F8 \\
\hline F1 & $\begin{array}{l}\text { Korelasyon } \\
\text { katsay1S1 }\end{array}$ &,- 007 &,$- 374^{* * *}$ &, 175 &, $366^{* * *}$ &, $392^{* * *}$ &,$- 274^{* *}$ &,- 076 \\
\hline F2 & $\begin{array}{l}\text { Korelasyon } \\
\text { katsayis1 }\end{array}$ & - &, $281^{* * *}$ & ,065 & ,122 &,- 177 &,- 150 & ,023 \\
\hline F3 & $\begin{array}{l}\text { Korelasyon } \\
\text { katsayis1 }\end{array}$ & - & - &,- 059 & ,067 &,$- 222^{*}$ &, $431^{* *}$ & ,213* \\
\hline F4 & $\begin{array}{l}\text { Korelasyon } \\
\text { katsay1s1 }\end{array}$ & - & - & - &, $272^{* * *}$ & ,125 &,- 149 &,- 128 \\
\hline F5 & $\begin{array}{l}\text { Korelasyon } \\
\text { katsayis1 }\end{array}$ & - & - & - & - &, $392^{* * *}$ & ,189 &,- 030 \\
\hline F6 & $\begin{array}{l}\text { Korelasyon } \\
\text { katsay1s1 }\end{array}$ & - & - & - & - & - & ,077 &,- 108 \\
\hline F7 & $\begin{array}{l}\text { Korelasyon } \\
\text { katsayıs1 }\end{array}$ & - & - & - & - & - & & ,131 \\
\hline
\end{tabular}

$\mathrm{p}<0,05=0, \mathrm{xx}^{*} ; \mathrm{p}<0,01=0, \mathrm{xx}^{* *}$

F1: Gereksinimlerin karşılanması ve memnuniyet düzeyi, F2: Rekreasyonel alanların yeterlilik düzeyi, F3: Ulaşılabilirlik düzeyi, F4: Rekreasyonel alanların önemi, F5: Ailenin aylık geliri, F6: Öğrencinin aylık geliri, F7: Rekreasyonel aktiviteye ayrılan süre, F8: Geldiği yerdeki imkânları Çankırı'da bulabilme durumu

Korelasyon analizine dâhil edilen yukarıdaki 8 faktör, aynı zamanda Ki Kare analizine tabi tutulmuştur. Bu faktörlerle birlikte kullanıcı özellikleri de değerlendirmeye alınmış ve anlamlı ilişkiler istatistiksel olarak incelenmiştir (p < 
0,05). Elde edilen sonuçlara göre; cinsiyet ile diğer birçok faktörün birbirleriyle ilişkili olduğu görülmüşsür. Buradan hareketle, sonuçlara bakarak cinsiyetin rekreasyonel eğilim ve taleplerin belirlenmesinde önemli etkisinin olduğu söylenebilir. Buna göre; kadınların çok büyük bir bölümü açık doğal alanları tercih etmekte iken, erkekler açık doğal alanların yanında teknolojik faaliyet alanların da tercih etmektedir. Erkekler kadınlara göre rekreasyon alanlarından daha memnun gözükmekte iken; kadınlar rekreasyon alanlarını daha önemli görmektedir. Bu durum; kadınların rekreasyon alanlarına olan yüksek hassasiyetlerinin ya da bu alanlara verdikleri önemin, alan memnuniyetlerinde daha titiz bir değerlendirmeye yol açtığı ve bu nedenle memnuniyet değerlerinin düştüğü şeklinde savunulabilir. Ayrıca, hem erkek hem de kadınların büyük çoğunluğunun aktivitelere 4 saate kadar zaman ayırdıkları ve geldikleri yerdeki rekreasyonel olanakları Çankırı'da bulamadıkları araştırmadan elde edilen sonuçlardan bazılarıdır. Buna karşın, rekreasyonel aktivitelere 4 saatten daha fazla zaman harcayan erkeklerin oranı kadınlara göre daha fazladır (Tablo 5). Bunun nedeni olarak, kadınların erkeklere oranla güvenliğe daha fazla önem vermesi ve akşam saatlerinde güvenlik tehdidinin artması (Johnson vd., 2001), alandaki aktivitelerin güce dayalı olabilmesi ya da kadınların ekonomik durumunun erkeklere nazaran alt seviyelerde olması (Aşıkkutlu, 2008) gösterilebilir.

Bununla birlikte; rekreasyon alanlarından gereksinimlerin karşılanması ve memnuniyet düzeyi noktasında, Mühendislik $(\% 75)$ ve Orman Fakülteleri'nde $(\% 71,4)$ okuyan öğrenciler Güzel Sanatlar, İktisadi İdari Bilimler, Meslek Yüksekokulu, Fen Edebiyat Fakülte öğrencilerine göre daha yüksek yüzdeye sahiptir. Bu sonuçların alınmasında "ailenin aylık geliri” ve "öğrencinin aylık geliri” faktörleri etkili olmuş olabilir. Çünkü bu iki faktörün öğrencilerin öğrenim gördükleri fakülteler ile anlamlı ilişki içerisinde olduğu ve özellikle orman ve mühendislik fakültesi öğrencilerinin gelir düzeylerinin diğer fakülte öğrencilerine nazaran daha yüksek olduğu Tablo 5 'ten anlaşılmaktadır $(\mathrm{p}<0,05)$. Tablo 4'e bakıldığında ise; öğrencinin ailesinin ve kendisinin gelir düzeyindeki artışın, rekreasyonel gereksinimlerinde ve memnuniyet düzeyinde de önemli ölçüde artı̧̧a yol açtığı görülmektedir. Johnson vd. (2001) ve Sıvalıoğlu'nun (2012) çalı̧̧malarındaki sonuçların bu çalışmadaki sonuçlarla paralellik gösterdiği söylenebilir. Buradan hareketle; öğrencilerin gelir düzeylerinin rekreasyonel ihtiyaçların giderilmesine ve alan memnuniyetine olumlu yönde doğrudan etki ettiği söylenebilir.

Rekreasyon alanlarının kullanım özellikleri arasındaki anlamlı ilişkiler Ki Kare analizi ile incelenmiştir $(\mathrm{p}<0,05)$. Alınan sonuçlara göre; alanların kullanım-hizmet durumları; "Gereksinimlerin karşılanması ve memnuniyet düzeyi”, "Rekreasyonel alanların önemi”, "Geldiği yerdeki koşulları Çankırı'da bulabilme durumu" ve "Rekreasyonel faaliyet tipleri” üzerinde anlamlı düzeyde etkili olmaktadır $(\mathrm{p}<0,05)$. Sonuçlara bakıldığında, alanların kullanım-hizmet durumunun 6 faktörden 4'ü üzerinde etkiye sahip olması nedeniyle, rekreasyonel eğilim ve taleplerin belirlenmesinde önemli etkisinin olduğu söylenebilir. Alanların kullanım-hizmet durumu bakımından faktörler arasındaki ilişkiler değerlendirildiğinde; bakımlı, güzel ve yeşil bir alanda rekreatif aktivitede bulunmak isteyen öğrenciler, bu alanlardan memnun kalmakta ve rekreasyonel ihtiyaçlarını bu alanlardan karşılamaktadır. Yücel'in (2007) çalışmasında da buradaki sonuçlara benzer sonuçlar elde edildiği belirlenmiştir. Bunun yanında, öğrencilerin kullanışlı alanlardan memnuniyetleri net olmamakla birlikte; öğrencilerin bir bölümü kullanışsız, bakımsız ve gürültülü alanlardan ilginç bir biçimde memnun kalmaktadır. Bu sonucun alınmasının altında yatan neden, tam olarak anlaşılamamakla birlikte mutlaka araştırılmalıdır. Öğrencilerin sorulara objektif cevap vermemesi ihtimal dâhilinde olabilir. Ayrıca, kullanışsız ve bakımsız durumdaki rekreasyon alanlarıyla karşılaşan öğrencilerin büyük bir kısmı, rekreasyon alanlarını önemli görmektedir. Bu sonuç, kullanışsız ve bakımsız alanların öğrenciler üzerindeki olumsuz etkilerini (Çakcı ve Çelem, 2009; Tepe, 2010; Talay vd., 2010) ortaya koymaktadır (Tablo 6).

Bunun yanında, rekreasyonel faaliyet alan tipleri ve alanlara ulaşım durumu da faktörler üzerinde etkili olmaktadır. Sonuçlara göre; açık doğal alanları tercih eden öğrenciler rekreasyon alanlarının önemli olduğunu düşünmekte, kapalı alanları tercih edenlerin büyük çoğunluğu ise bu alanları önemsiz olarak görmektedir. Ayrıca ulaşım durumu bakımından, toplu taşıma ve şahsi araç tercih edenler yaya olarak ulaşım sağlayanlara göre rekreasyon alanlarından daha çok memnun kalmakta ve gereksinimleri karşılanmaktadır (Tablo 6). Benzer şekilde, Gold (1980) rekreasyonel alanlara ulaşım kolaylığının rekreasyonel talebi pozitif yönde etkilediğini belirtmektedir. Sıvalığlu (2012) ise; alana erişim kolaylığının alana bağlılığı pozitif yönde etkilediğini ve bunun da genel memnuniyeti artırdığını ifade etmiştir. Toplu taşımayı tercih edenler rekreasyon alanlarını önemli bulurken (Sıvalığlu, 2012) buna karşın, şahsi araç tercih edenler ise rekreasyon alanlarını yetersiz bulmaktadır. 
Tablo 5. Kullanıcı özellikleri ile rekreasyon alanlarının kullanım özellikleri arasındaki anlamlı ilişkiler (Ki Kare Analizi)

\begin{tabular}{|c|c|c|c|c|c|c|c|c|c|c|c|c|c|c|c|}
\hline & \multicolumn{4}{|c|}{ CINSIYYT } & \multicolumn{6}{|c|}{ ÖĞRENIM GÖRDÜĞÜ FAKÜLTE } & \multicolumn{5}{|c|}{ KALDIĞI YER } \\
\hline & GRUPLAR & Erkek & Kadın & $\begin{array}{c}\text { Chi square } \\
\quad\left(X^{2}\right) \\
\mathbf{P}<\mathbf{0 , 0 5}\end{array}$ & GSF & İBF & MYO & $\begin{array}{l}\text { Mühendis } \\
\text { lik }\end{array}$ & Orman & $\begin{array}{c}\text { Fen } \\
\text { Edebiyat }\end{array}$ & $\begin{array}{c}\text { Chi } \\
\text { square } \\
\left(X^{2}\right) \\
\mathbf{P}<0,05\end{array}$ & Ev & Yurt & Apart & $\begin{array}{c}\text { Chi } \\
\text { square } \\
\left(X^{2}\right) \\
\text { P }<0,05\end{array}$ \\
\hline $\begin{array}{l}\text { REKREASYONEL } \\
\text { FAALIYET } \\
\text { ALANLARI }\end{array}$ & $\begin{array}{l}\text { Açık doğal alanlar } \\
\text { Kapalı alanlar } \\
\text { Teknolojik faaliyet alanları }\end{array}$ & $\begin{array}{l}46,9 \% \\
10,2 \% \\
42,9 \%\end{array}$ & $\begin{array}{l}78,7 \% \\
6,4 \% \\
14,9 \%\end{array}$ & $\begin{array}{c}10,730 \\
p=0,005\end{array}$ & & & & & & & & $\begin{array}{l}48,3 \% \\
12,1 \% \\
39,7 \%\end{array}$ & $\begin{array}{l}93,8 \% \\
0,0 \% \\
6,2 \%\end{array}$ & $\begin{array}{l}77,3 \% \\
4,5 \% \\
18,2 \%\end{array}$ & $\begin{array}{c}13,808 \\
p=0,008\end{array}$ \\
\hline ULAŞIM DURUMU & $\begin{array}{l}\text { Toplu taşıma } \\
\text { Kişisel araç } \\
\text { Yaya } \\
\end{array}$ & $\begin{array}{l}20,4 \% \\
40,8 \% \\
38,8 \% \\
\end{array}$ & $\begin{array}{l}53,2 \% \\
25,5 \% \\
21,3 \% \\
\end{array}$ & $\begin{array}{c}11,185 \\
p=0,004\end{array}$ & & & & & & & & $\begin{array}{l}20,7 \% \\
41,4 \% \\
37,9 \% \\
\end{array}$ & $\begin{array}{l}75,0 \% \\
12,5 \% \\
12,5 \% \\
\end{array}$ & $\begin{array}{l}50,0 \% \\
27,3 \% \\
22,7 \% \\
\end{array}$ & $\begin{array}{c}18,247 \\
p=0,001\end{array}$ \\
\hline $\begin{array}{l}\text { GEREKSINIMLERIN } \\
\text { KARŞILANMASI VE } \\
\text { MEMNUNIYET } \\
\text { DÜZEYİ (F1) } \\
\end{array}$ & $\begin{array}{l}\text { Kesinlikle katılmıyorum } \\
\text { Katılmiyorum } \\
\text { Fikrim yok } \\
\text { Katıliyorum } \\
\text { Kesinlikle katıliyorum }\end{array}$ & $\begin{array}{l}2,0 \% \\
22,4 \% \\
22,4 \% \\
20,4 \% \\
32,8 \% \\
\end{array}$ & $\begin{array}{l}29,8 \% \\
14,9 \% \\
8,5 \% \\
8,5 \% \\
38,3 \% \\
\end{array}$ & $\begin{array}{c}18,077 \\
\mathbf{p}=\mathbf{0 , 0 0 1}\end{array}$ & $\begin{array}{l}25,6 \% \\
30,8 \% \\
25,6 \% \\
10,3 \% \\
7,7 \% \\
\end{array}$ & $\begin{array}{l}0,0 \% \\
0,0 \% \\
15,8 \% \\
26,3 \% \\
57,9 \% \\
\end{array}$ & $\begin{array}{l}11,8 \% \\
23,5 \% \\
0,0 \% \\
17,6 \% \\
47,1 \% \\
\end{array}$ & $\begin{array}{l}0,0 \% \\
0,0 \% \\
0,0 \% \\
25,0 \% \\
75,0 \% \\
\end{array}$ & $\begin{array}{l}0,0 \% \\
14,3 \% \\
14,3 \% \\
0,0 \% \\
71,4 \% \\
\end{array}$ & $\begin{array}{l}30,0 \% \\
10,0 \% \\
10,0 \% \\
10,0 \% \\
40,0 \% \\
\end{array}$ & $\begin{array}{c}42,763 \\
p=0,002\end{array}$ & & & & \\
\hline $\begin{array}{l}\text { REKREASYONEL } \\
\text { ALANLARIN ÖNEMI } \\
\text { (F4) }\end{array}$ & $\begin{array}{l}\text { Kesinlikle katılmıyorum } \\
\text { Katılmiyorum } \\
\text { Fikrim yok } \\
\text { Katıliyorum } \\
\text { Kesinlikle katıliyorum }\end{array}$ & $\begin{array}{l}14,3 \% \\
8,2 \% \\
14,3 \% \\
20,4 \% \\
42,9 \% \\
\end{array}$ & $\begin{array}{l}10,6 \% \\
4,3 \% \\
8,5 \% \\
4,3 \% \\
72,3 \% \\
\end{array}$ & $\begin{array}{c}\mathbf{1 0 , 1 8 7} \\
p=0,037\end{array}$ & & & & & & & & & & & \\
\hline $\begin{array}{l}\text { AİLENİ AYLIK } \\
\text { GELIRİ (F5) }\end{array}$ & $\begin{array}{l}1000-2500 \mathrm{TL} \\
2500-4000 \mathrm{TL} \\
4000 \text { TL ve üzeri } \\
\end{array}$ & & & & $\begin{array}{l}41,0 \% \\
56,4 \% \\
2,6 \% \\
\end{array}$ & $\begin{array}{l}5,3 \% \\
89,4 \% \\
5,3 \% \\
\end{array}$ & $\begin{array}{l}35,3 \% \\
52,9 \% \\
11,8 \% \\
\end{array}$ & $\begin{array}{l}0,0 \% \\
100 \% \\
0,0 \% \\
\end{array}$ & $\begin{array}{l}0,0 \% \\
100 \% \\
0,0 \% \\
\end{array}$ & $\begin{array}{l}10,0 \% \\
70,0 \% \\
20,0 \% \\
\end{array}$ & $\begin{array}{c}20,988 \\
p=0,021\end{array}$ & & & & \\
\hline $\begin{array}{l}\text { ÖĞRENCININ AYLIK } \\
\text { GELIRİ (F6) }\end{array}$ & $\begin{array}{l}400-800 \mathrm{TL} \\
800-1200 \mathrm{TL} \\
1200-2000 \mathrm{TL} \\
\end{array}$ & $\begin{array}{l}50,0 \% \\
45,8 \% \\
4,2 \% \\
\end{array}$ & $\begin{array}{l}76,1 \% \\
23,9 \% \\
0,0 \% \\
\end{array}$ & $\begin{array}{c}7,678 \\
p=0,022\end{array}$ & $\begin{array}{l}81,6 \% \\
18,4 \% \\
0,0 \% \\
\end{array}$ & $\begin{array}{l}57,9 \% \\
42,1 \% \\
0,0 \% \\
\end{array}$ & $\begin{array}{l}35,3 \% \\
58,8 \% \\
5,9 \% \\
\end{array}$ & $\begin{array}{l}50 \% \\
50 \% \\
0,0 \% \\
\end{array}$ & $\begin{array}{l}16,7 \% \\
66,7 \% \\
16,7 \% \\
\end{array}$ & $\begin{array}{l}80,0 \% \\
20,0 \% \\
0,0 \% \\
\end{array}$ & $\begin{array}{c}24,073 \\
p=0,007\end{array}$ & $\begin{array}{l}50,0 \% \\
46,4 \% \\
3,6 \%\end{array}$ & $\begin{array}{l}87,5 \% \\
12,5 \% \\
0,0 \% \\
\end{array}$ & $\begin{array}{l}77,3 \% \\
22,7 \% \\
0,0 \%\end{array}$ & $\begin{array}{c}10,433 \\
p=0,034\end{array}$ \\
\hline $\begin{array}{l}\text { AKTIVITEYE } \\
\text { AYRILAN SÜRE (F7) }\end{array}$ & $\begin{array}{l}0-2 \text { saat } \\
2-4 \text { saat } \\
4-6 \text { saat } \\
6-8 \text { saat } \\
8 \text { saat ve üzeri }\end{array}$ & $\begin{array}{l}10,2 \% \\
53,1 \% \\
26,5 \% \\
2,0 \% \\
8,2 \% \\
\end{array}$ & $\begin{array}{l}40,4 \% \\
38,3 \% \\
19,1 \% \\
2,1 \% \\
0,0 \%\end{array}$ & $\begin{array}{c}14,313 \\
p=0,006\end{array}$ & & & & & & & & & & & \\
\hline $\begin{array}{l}\text { GELDIĞİ YERDEKİ } \\
\text { DURUMU } \\
\text { ÇANKIRI'DA } \\
\text { BULABİLME } \\
\text { DURUMU (F8) }\end{array}$ & $\begin{array}{l}\text { Hayır } \\
\text { Kararsızım } \\
\text { Evet }\end{array}$ & $\begin{array}{l}85,7 \% \\
12,2 \%\end{array}$ & $\begin{array}{l}95,7 \% \\
0,0 \% \\
4,3 \%\end{array}$ & $\begin{array}{c}6,398 \\
p=0,041\end{array}$ & & & & & & & & & & & \\
\hline
\end{tabular}


Tablo 6. Rekreasyon alanlarının kullanım özellikleri arasındaki anlamlı ilişkiler (Ki Kare Analizi)

\begin{tabular}{|c|c|c|c|c|c|c|c|c|c|c|c|c|c|c|c|c|}
\hline & & & $\begin{array}{l}\text { KREASY } \\
\text { FAALIY } \\
\text { ALANLA }\end{array}$ & & & ALAl & NLARIN K & KULLANII & M - HİZM & IET DURI & UMU & & ULA & SIM DUI & UMU & \\
\hline & GRUPLAR & $\begin{array}{l}\text { Açık } \\
\text { doğal } \\
\text { alanlar }\end{array}$ & $\begin{array}{l}\text { Kapalı } \\
\text { alanlar }\end{array}$ & $\begin{array}{l}\text { Tekn. } \\
\text { faaliyet } \\
\text { alanları }\end{array}$ & $\begin{array}{c}\text { Chi square } \\
\quad\left(X^{2}\right) \\
\mathbf{P}<0,05\end{array}$ & Kullanışlı & $\begin{array}{l}\text { Kullanışsı } \\
\mathrm{z}\end{array}$ & $\begin{array}{l}\text { Temiz } \\
\text { güzel ve } \\
\text { yeşil bir } \\
\text { çevre }\end{array}$ & Kirli & Gürültülü & Diğer & $\begin{array}{c}\text { Chi square } \\
\quad\left(X^{2}\right) \\
\mathbf{P}<\mathbf{0 , 0 5}\end{array}$ & $\begin{array}{l}\text { Toplu } \\
\text { taşıma }\end{array}$ & $\begin{array}{c}\text { Kişisel } \\
\text { araç }\end{array}$ & Yaya & $\begin{array}{c}\text { Chi square } \\
\quad\left(X^{2}\right) \\
\mathbf{P}<\mathbf{0 , 0 5}\end{array}$ \\
\hline \multirow{5}{*}{$\begin{array}{l}\text { GEREKSINIMLERİ } \\
\text { KARŞILANMASI VE } \\
\text { MEMNUNIYET } \\
\text { DÜZEYİ (F1) }\end{array}$} & $\begin{array}{l}\text { Kesinlikle } \\
\text { kat1lmıyorum }\end{array}$ & & & & & $18,2 \%$ & $20,4 \%$ & $0,0 \%$ & $0,0 \%$ & $0,0 \%$ & $0,0 \%$ & \multirow{5}{*}{$\begin{array}{c}41,902 \\
p=0,003\end{array}$} & $8,6 \%$ & $9,4 \%$ & $31,0 \%$ & \multirow{5}{*}{$\begin{array}{c}32,201 \\
\mathbf{p}=\mathbf{0 , 0 0 0}\end{array}$} \\
\hline & Katılmiyorum & & & & & $9,1 \%$ & $18,5 \%$ & $0,0 \%$ & $40,0 \%$ & $30,0 \%$ & $50,0 \%$ & & $8,6 \%$ & $15,6 \%$ & $34,5 \%$ & \\
\hline & Fikrim yok & & & & & $45,4 \%$ & $5,6 \%$ & $0,0 \%$ & $0,0 \%$ & $10,0 \%$ & $50,0 \%$ & & $8,6 \%$ & $15,6 \%$ & $24,1 \%$ & \\
\hline & Katıliyorum & & & & & $18,2 \%$ & $9,3 \%$ & $66,7 \%$ & $20,0 \%$ & $20,0 \%$ & $0,0 \%$ & & $14,2 \%$ & $25,0 \%$ & $3,5 \%$ & \\
\hline & $\begin{array}{l}\text { Kesinlikle } \\
\text { kat1liyorum }\end{array}$ & & & & & $9,1 \%$ & $46,2 \%$ & $33,3 \%$ & $40,0 \%$ & $40,0 \%$ & $0,0 \%$ & & $60,0 \%$ & $34,4 \%$ & $6,9 \%$ & \\
\hline \multirow{3}{*}{$\begin{array}{l}\text { REKREASYONEL } \\
\text { ALANLARIN } \\
\text { YETERLİLIK DÜZEYİ } \\
(\mathrm{F} 2)\end{array}$} & Hayır & & & & & & & & & & & & $40,0 \%$ & $71,9 \%$ & $44,8 \%$ & \multirow{3}{*}{$\begin{array}{c}10,510 \\
p=0,033\end{array}$} \\
\hline & i Kararsızım & & & & & & & & & & & & $51,4 \%$ & $25,0 \%$ & $55,2 \%$ & \\
\hline & Evet & & & & & & & & & & & & $8,6 \%$ & $3,1 \%$ & $0,0 \%$ & \\
\hline \multirow{5}{*}{$\begin{array}{l}\text { REKREASYONEL } \\
\text { ALANLARIN ÖNEMİ } \\
\text { (F4) }\end{array}$} & $\begin{array}{l}\text { Kesinlikle } \\
\text { katılmiyorum }\end{array}$ & $6,7 \%$ & $62,5 \%$ & $10,7 \%$ & \multirow{5}{*}{$\begin{array}{c}27,777 \\
p=0,001\end{array}$} & $36,4 \%$ & $1,9 \%$ & $33,3 \%$ & $0,0 \%$ & $20,0 \%$ & $0,0 \%$ & \multirow{5}{*}{$\begin{array}{c}67,063 \\
p=0,000\end{array}$} & $14,3 \%$ & $21,9 \%$ & $0,0 \%$ & \multirow{5}{*}{$\begin{array}{c}16,903 \\
p=0,031\end{array}$} \\
\hline & Katılmiyorum & $6,7 \%$ & $12,5 \%$ & $3,6 \%$ & & $13,6 \%$ & $1,9 \%$ & $33,3 \%$ & $20,0 \%$ & $0,0 \%$ & $0,0 \%$ & & $2,9 \%$ & $9,4 \%$ & $6,9 \%$ & \\
\hline & Fikrim yok & $8,3 \%$ & $25,0 \%$ & $14,3 \%$ & & $13,6 \%$ & $3,7 \%$ & $0,0 \%$ & $0,0 \%$ & $60,0 \%$ & $0,0 \%$ & & $2,9 \%$ & $15,6 \%$ & $17,2 \%$ & \\
\hline & Katıliyorum & $11,7 \%$ & $0,0 \%$ & $17,9 \%$ & & $4,5 \%$ & $14,8 \%$ & $0,0 \%$ & $20,0 \%$ & $20,0 \%$ & $0,0 \%$ & & $5,7 \%$ & $12,5 \%$ & $20,7 \%$ & \\
\hline & $\begin{array}{l}\text { Kesinlikle } \\
\text { kat1liyorum }\end{array}$ & $66,6 \%$ & $0,0 \%$ & $53,5 \%$ & & $31,8 \%$ & $77,8 \%$ & $33,3 \%$ & $60,0 \%$ & $0,0 \%$ & $100,0 \%$ & & $74,2 \%$ & $40,6 \%$ & $55,2 \%$ & \\
\hline \multirow{3}{*}{$\begin{array}{l}\text { ÖĞRENCIININ AYLIK } \\
\text { GELİRİ (F6) }\end{array}$} & $400-800 \mathrm{TL}$ & $78,0 \%$ & $42,9 \%$ & $35,7 \%$ & \multirow{3}{*}{$\begin{array}{c}18,306 \\
p=0,001\end{array}$} & & & & & & & & & & & \\
\hline & $800-1200 \mathrm{TL}$ & $22,0 \%$ & $57,1 \%$ & $57,1 \%$ & & & & & & & & & & & & \\
\hline & $1200-2000 \mathrm{TL}$ & $0,0 \%$ & $0,0 \%$ & $7,2 \%$ & & & & & & & & & & & & \\
\hline \multirow{4}{*}{$\begin{array}{l}\text { GELDİĞI YERDEKİ } \\
\text { DURUMU } \\
\text { ÇANKIRI'DA } \\
\text { BULABİLME } \\
\text { DURUMU (F8) } \\
\end{array}$} & Hayır & & & & & $95,5 \%$ & $92,5 \%$ & $100,0 \%$ & $80,0 \%$ & $80,0 \%$ & $50,0 \%$ & \multirow{3}{*}{$\begin{array}{c}19,646 \\
p=0,033\end{array}$} & & & & \\
\hline & Kararsızım & & & & & $4,5 \%$ & $5,6 \%$ & $0,0 \%$ & $20,0 \%$ & $10,0 \%$ & $0,0 \%$ & & & & & \\
\hline & Evet & & & & & $0,0 \%$ & $1,9 \%$ & $0,0 \%$ & $0,0 \%$ & $10,0 \%$ & $50,0 \%$ & & & & & \\
\hline & Go-kart & & & & & $19,4 \%$ & $61,1 \%$ & $5,6 \%$ & $0,0 \%$ & $13,9 \%$ & $0,0 \%$ & \multirow{4}{*}{$\begin{array}{ll}3 & \mathbf{3 3 , 1 5 7} \\
& \mathbf{p}=\mathbf{0 , 0 0 4} \\
& \end{array}$} & & & & \\
\hline \multirow{3}{*}{$\begin{array}{l}\text { REKREASYONEL } \\
\text { FAALIYET TIPII }\end{array}$} & Yüzme & & & & & $15,6 \%$ & $65,6 \%$ & $0,0 \%$ & $12,5 \%$ & $3,1 \%$ & $3,1 \%$ & & & & & \\
\hline & Lunapark & & & & & $32,0 \%$ & $44,0 \%$ & $4,0 \%$ & $4,0 \%$ & $16,0 \%$ & $0,0 \%$ & & & & & \\
\hline & Diğer & & & & & $66,7 \%$ & $0,0 \%$ & $0,0 \%$ & $0,0 \%$ & $0,0 \%$ & $33,3 \%$ & & & & & \\
\hline
\end{tabular}




\section{SONUÇ ve ÖNERILLER}

Elde edilen bulgular ile yapılan tartışma ve değerlendirmeler sonucunda, kent içi rekreasyonel planlama, uygulama ve faaliyetlere katkı sağlaması hedeflenen birtakım öneriler getirilmiştir. Buna göre:

- Çankırı'da öğrenim gören öğrencilerin büyük bir kısmının geliri oldukça düşüktür. Bu nedenle, öğrenciler dilediği aktiviteye kolayca erişememekte ve öğrencilerin gerçekleştirdiği rekreasyonel aktivite çeşidi azalmaktadır. Dolayısıyla, düşük gelirli öğrencilerin de faydalanabileceği aktivitelerin sayısı üniversitenin öğrenci potansiyeli de göz önünde bulundurularak kent genelinde arttırılmalıdır.

- Yüksek gelirli öğrencilerin rekreasyon için ayırdıkları kısa zaman dilimlerini fazla para ödeyerek daha etkin şekilde kullanmak istemeleri araştırmanın dikkat çeken sonuçları arasındadır. Bu bağlamda, gelir durumu iyi olan öğrencilerin ihtiyaçlarına cevap verebilecek rekreasyon alanlarının çeşidi ve kalitesi arttırılmalı ve bu alanlar cazibe merkezi haline getirilmelidir. Buna karşın, Çankırı genelinde bu koşulları yerine getirebilen az sayıda rekreasyon alanı bulunmaktadır. Eksikliklerin giderilmesi neticesinde öğrencilerin kent hakkındaki olumlu görüşleri arttırılabilir ve rekreasyon alanlarından memnun bir şekilde ayrılmaları sağlanabilir.

- Sonuçlara göre; rekreasyon alanlarına ulaşılabilirliğin artmasına paralel olarak aktivitelere ayrılan sürenin ve öğrencilerin geldiği yerdeki imkânları Çankırı'da bulabilme durumlarının da arttığı tespit edilmiştir. Ayrıca sonuçlar, ulaşılabilirlik düzeyindeki artışın alanların rekreasyon bakımından yeterliliğini arttırdığını göstermektedir. $\mathrm{Bu}$ noktada, özellikle düşük gelirli öğrenciler için kent içi rekreasyon alanlarına ulaşılabilirlik düzeyi arttırılarak, öğrencilerin kısa sürede daha çok aktiviteye ulaşması sağlanmalıdır. Böylece, birey daha fazla aktiviteye katılma imkânı bulacak ya da belli bir aktivitede daha uzun süre vakit geçirebilecektir. Buna paralel olarak, öğrenciler rekreasyon alanlarına ilişkin belli bir tatmin düzeyine ulaşabilecek ve Çankırı kenti rekreasyon alanlarını kendi şehirlerine kıyasladıklarında yeterli görmeye başlayacaklardır. Çalışmadaki, ulaşılabilirliğin rekreasyon alanlarının yeterliliğgini arttırdığı sonucu bu yaklaşımı doğrulamaktadır. Tüm bu olumlu sonuçların sağlanması için gerekli olan en önemli unsurlardan birisi ise; rekreasyon alanlarının öğrencilerin ikamet ettikleri ve öğrenim gördükleri yerlere yakın alanlarda konumlandırılması ve bu sayede öğrencilerin alana kolayca ulaşabilmesinin sağlanmasıdır.

- Araştırmanın önemli sonuçlarından bir diğeri ise; erkeklerin teknolojinin kullanıldığı rekreasyon alanlarını (dijital oyun alanları, internet kafeler, bilim fuarları vb.) tercih etme eğilimi göstermesi ve aktivitelere bayanlara göre daha çok süre ayırmalarıdır. Bu nedenle, bu tipteki rekreasyon alanlarının sayısı ve kapasitesi arttırılmalı ve bu alanlara öğrenciler kolaylıkla ulaş̧labilmelidir. Koşulların sağlanması neticesinde öğrenciler Çankırı'da birçok rekreasyonel imkâna kavuşabilecek ve dolayısıyla öğrencilerin kent hakkındaki olumlu düşünceleri ve memnuniyetleri arttırllabilecektir.

- Hem erkek hem de kadınlar açık doğal alanları diğer rekreasyon alanlarına göre daha çok tercih etmektedir. $\mathrm{Bu}$ sebeple, kent içi doğal karakterdeki açık-yeşil alanların sayısı ve kapasitesi arttırılmalı ya da doğal özelliklere sahip yeni rekreasyon alanları oluşturulmalıdır.

- Öğrenciler genel olarak kullanışsız ve kirli durumdaki rekreasyon alanlarına hassasiyet göstermekte, buna karşın temiz, güzel ve yeşil bir alanda rekreasyon yapmak isteyen öğrenciler, bu alanlardan memnun kalmaktadır. Alınan bu sonuç, rekreasyon alanlarındaki denetim ve bakım çalışmalarının önemini ortaya koymaktadır. Doğal alanlarda rekreasyon yapma ve bu alanların yaşam kalitesi için önemli olduğunu düşünme hassasiyetinde olan öğrencilerin çalışmada yüksek oranlarla tespit edildiği dikkate alınırsa, kent içi rekreasyon kalitesini arttırma hedeflerine ulaşma adına rekreasyon alanlarında bakım ve denetim tedbirleri alınarak, peyzaj çalışmaları yapılmalıdır. Araştırma sonuçlarına bakıldığında doğal alanları tercih eden öğrencilerin rekreasyon alanlarını önemli gördüğü açıkça görülmektedir.

Sonuç olarak; yapılan çalışma neticesinde tespit edilen sonuç ve önerilerin objektif bir biçimde değerlendirilmesi ve hayata geçirilmesi noktasında belediye ve ilgili kamu ile özel kurum ve kuruluşlara önemli görevler düşmektedir. Çalışma kapsamında tespit edilen sorunlar ve problemlere getirilen çözüm önerilerinin detaylıca irdelenerek rekreasyon alanlarında gereken önlemlerin pratik bir biçimde alınması oldukça önem arz etmektedir. Neticede, Çankırı kentinde konuyla ilgili hızlı bir şekilde eyleme geçilmesi sağlanarak, kent ve üniversitenin gelişimi açısından oldukça önemli bir unsur olan öğrencinin yaşam kalitesinin arttırılması ve rekreasyon alanlarına olan bakış açılarının 
geliştirilerek memnuniyet düzeylerinin yukarıya çekilmesi arzu edilmektedir. Hedeflenen koşullar sağlandığında, kent ve üniversite açısından öğrenci potansiyelinin günden güne artacağı düşünülmektedir.

\section{Etik Standart ile Uyumluluk}

Çıkar Çatışması: Yazarlar herhangi bir çıkar çatışmasının olmadığını beyan eder.

Etik Kurul İzni: Bu çalışma için etik kurul iznine gerek yoktur.

Finansal Destek: Yok.

\section{Teşekkür}

Bu çalışmada emeği bulunan Çankırı Karatekin Üniversitesi Peyzaj Mimarlığı Bölümü lisans öğrencilerinden Abdullah Sefa ÇELİK, Ayşe ÖZDEMİ, Emre BAL, Enes ÇEKER, Miyase Nur ERCIYES, Özge GÜNDOĞDU ve Yeşim KARAKAYA'ya katkılarından dolayı teşekkür ederiz.

\section{KAYNAKÇA}

Anonim, (2010). Çankırı İl Çevre Durum Raporu. T.C. Çankırı Valiliği İl Çevre ve Orman Müdürlü̆̈̈̈, 279 s., Çankırı.

Aşıkkutlu, H. S. (2008). Rekreasyonel Motivasyon ve Kısıtlayıcılar; Ankara Göksu Parkı ve Harikalar Diyarı Parkı Örneği. Yüksek Lisans Tezi. Düzce Üniversitesi Fen Bilimleri Enstitüsü, 134 s. Düzce.

Bell, S. (1997). Design for Outdoor Recreation. Spon Press First Edition Book, Taylor \& Francis Group. ISBN 0203-37491-6. London, UK.

Bilgili, B. C. (2013). Çankırı kenti kamusal yeşil alanlarının yeterliliğinin ulaşılabilirlik yönünden değerlendirilmesi. Tekirdağ Ziraat Fakültesi Dergisi, 10(2), 21-25.

Bryant, J. A., Banta, T. W., \& Bradley, J. L. (1995). Assessment provides insight into the impact and effectiveness of campus recreation programs. NASPA journal, 32(2), 153-160.

Çakci, I., \& Çelem, H. (2009). Kent parklarında görsel peyzaj algısının değerlendirilmesi. Tarım Bilimleri Dergisi, 15(1), 88-95.

Çoruh, Y., \& Karaküçük, S. (2014). Üniversite öğrencilerinin cinsiyet değişkenine göre rekreasyonel eğilimleri ve rekreasyonel etkinliklere katılımına engel olan faktörler. International Journal of Sport Culture and Science, 2 (Special Issue 1), 854-862. ISSN: 2148-1148, Doi : 10.14486/IJSCS159.

Ekal, S. K. (2009). Büyük Antakya Parkı'nın Rekreasyonel Talep Özelliklerinin Saptanması. Yüksek Lisans Tezi. İstanbul Üniversitesi Fen Bilimleri Enstitüsü Orman Mühendisliği Anabilim Dalı. 108 s. İstanbul.

Gold, S. M. (1980). Recretion Planning and Desing. McGraw-Hill Book Comp., Newyork.

Jim, C. Y., \& Chen, W. Y. (2006). Recreation-amenity use and contingent valuation of urban greenspaces in Guangzhou, China. Landscape and urban planning, 75(1-2), 81-96.

Johnson, C. Y., Bowker, J. M., \& Cordell, H. K. (2001). Outdoor recreation constraints: An examination of race, gender, and rural dwelling. Southern Rural Sociology, 17, 111-133.

Karaşah, B. (2017). Kentsel ve kırsal rekreasyon alanlarına yönelik kullanıcı tercihlerinin belirlenmesi 'Artvin kenti örneği’. Bartın Orman Fakültesi Dergisi, 19(1), 58-69.

Kaya, F. (2007). Bartın Kent Halkının Rekreasyonel Eğilim Ve Taleplerinin Belirlenmesi Üzerine Bir Araştırma. Yüksek Lisans Tezi. Ankara Üniversitesi Fen Bilimleri Enstitüsü Peyzaj Mimarlığı Anabilim Dalı. 158 s. Ankara. 
Kiper, T. (2009). Namık Kemal Üniversitesi Ziraat Fakültesi (Tekirdağ) öğrencilerinin rekreasyonel eğilim ve taleplerinin belirlenmesi. Tekirdağ Ziraat Fakültesi Dergisi, 6(2), 191-201, Tekirdăg.

Lindsey, R., \& Sessoms, E. (2006). Assessment of a campus recreation program on student recruitment, retention, and frequency of participation across certain demographic variables. Recreational Sports Journal, 30(1), 30-39.

Mansuroğlu, S. (2002). Akdeniz üniversitesi öğrencilerinin serbest zaman özellikleri ve dış mekan rekreasyon eğilimlerinin belirlenmesi. Akdeniz Üniversitesi Ziraat Fakültesi Dergisi, 15(2), 53-62.

Noe, F. P., \& Uysal, M. (1997). Evaluation of outdoor recreational settings: A problem of measuring user satisfaction. Journal of Retailing and Consumer Services, 4(4), 223-230.

Önder, S. (2003). Selçuk Üniversitesi öğrencilerinin rekreasyonel eğilim ve taleplerinin belirlenmesi üzerinde bir araştırma. Selçuk Üniversitesi Ziraat Fakültesi Dergisi, 17(32), 31-38.

Özdamar, K. (2013). Paket Programlar İle İstatistiksel Veri Analizi (Cilt 1-2). Ankara: Nisan Kitapevi. ISBN: 978975-6428-51-1.

Sağlık, A., \& Kelkit, A. (2014). Çanakkale kent halkının rekreasyonel eğilim ve taleplerinin belirlenmesi. ÇOMÜ Ziraat Fakültesi Dergisi, 2(1), 27-36.

Sıvalığlu, P. (2012). Milli Park Kullanıcılarının Algısal Değerlendirmesi: Marmara Bölgesi Örneği. Doktora Tezi, İstanbul Teknik Üniversitesi, İstanbul.

Şahin, C. K., Akten, S., \& Erol, U. E. (2011). Eğirdir meslek yüksekokulu öğrencilerinin rekreasyon faaliyetlerine katılımlarının belirlenmesi üzerine bir çalışma. Artvin Çoruh Üniversitesi Orman Fakültesi Dergisi, 10(1), 62-71.

Şişman, E. E. \& Özyavuz, M. (2016). Tekirdağ kent halkının parklar hakkındaki görüşlerinin belirlenmesi. Uluslararası Hakemli Tasarım ve Mimarlık Dergisi, 7(1): 29-41.

Talay, İ., Kaya, F., \& Belkayalı, N. (2010). Sosyo-ekonomik yapının rekreasyonel eğilim ve talepler üzerine etkisi: Bartın kenti örneği. Coğrafi Bilimler Dergisi/Turkish Journal of Geographical Sciences, 8(2), 147-156.

Tepe, A. C. (2010). Tarihi Gülhane Parkı Yenileme Çalışmaları ve Kullanıcı Memnuniyeti. Yüksek Lisans Tezi. Bartın Üniversitesi, Fen Bilimleri Enstitüsü, Bartın.

Tuna, F. (2010). Çankırı'nın coğrafi özelliklerinin şehirsel gelişim potansiyeli yönünden değerlendirilmesi. Marmara Coğrafya Dergisi, 21, 219-239.

URL-1. İllere Göre Ekonomik Gelişmişlik https://www.cnnturk.com/2012/ekonomi/genel/05/25/illerin.sosyo.ekonomik.gelismislik.siralamasi.guncellendi/66242 0.0/index.html. Erişim Tarihi: 04.06.2018.

Yalçınyavuz, A. Ü. (2015). Erzincan Kenti Rekreasyon Alanları Kullanıcı Tercihlerinin Anketle Analizi. Yüksek Lisans Tezi. Atatürk Üniversitesi Fen Bilimleri Enstitüsü Peyzaj Mimarlı̆̆g Anabilim Dalı. 137 s. Erzurum.

Yalçınyavuz, A. Ü., \& Yılmaz, S. (2016). Rekreasyonel alan kullanım taleplerinin belirlenmesi: Erzincan kenti örneği. Kastamonu Üniversitesi Orman Fakültesi Dergisi, 16(2): 336-347.

Yazıcıŏlu, Y. \& Erdoğan, S. (2004). SPSS Uygulamalı Bilimsel Araştırma Yöntemleri. Detay Yayıncılık, S: 50. Ankara.

Yılmaz, H., Yılmaz, S., \& Yıldız, N. D. (2003). Kars kent halkının rekreasyonel talep ve eğilimlerinin belirlenmesi. Atatürk Üniversitesi Ziraat Fakültesi Dergisi, 34(4), 353-360.

Yücel, G. F. (2007). Park alanlarında kullanıcı memnuniyeti açısından bakımın önemi. MEGARON/Yıldız Teknik Üniversitesi, Mimarlık Fakültesi E-Dergisi, 2(3), 176-187. 